\title{
Curriculum Design for Postgraduate Program of Islamic Study at UIN Raden Fatah Palembang During the Covid-19 Pandemic
}

\author{
Ahmad Zainuri*, Aflatun Muchtar, Yusron Masduki \\ UIN Raden Fatah Palembang \\ Palembang, Indonesia \\ *ahmadzainuri_uin@radenfatah.ac.id, aflatun_m@yahoo.com,yusron.masduki@pai.uad.ac.id
}

\begin{abstract}
During the Covid-19 pandemic, the learning process at the Islamic Studies Study Program, Postgraduate Program, UIN Raden Fatah Palembang was carried out online (long distance), so that lecturers were required to be creative in designing the learning curriculum. The curriculum design is structured as concise and as simple as possible, so that the delivery of course material (lecture method) can be implemented effectively and efficiently. The Semester Learning Plan (RPS) does not have to be changed, but needs to be adjusted to a learning process that is suitable for the conditions during the Covid-19 pandemic, which is the e-learning process.
\end{abstract}

Keywords-the Covid-19 epidemic, learning curriculum design and SI study program

\section{INTRODUCTION}

This paper aims to explain the design of the learning curriculum in the Islamic Studies Study Program (Prodi SI), Pascarasajana Program (PPs) UIN Raden Fatah Palembang, during the Covid-19 epidemic. This case study is important to carry out, because with the outbreak of the Covid-19 epidemic, the government, both central and regional, needs to take preventive steps through Large-Scale Social Restrictions (PSBB) and social distancing which have a direct impact on the learning process in the SI Study Program, PPs, UIN Raden Fatah Palembang. Furthermore, the Ministry of Education and Culture has issued Circular letter (SE) Number 4 of 2020 concerning Implementation of Education Policies in an Emergency for the Spread of Covid-19 [1]. The content of the circular leter is that the learning process can be carried out at home through distance learning methods (online).

This policy has changed the learning method that has been carried out face-to-face in the lecture hall into using online learning technology. This condition requires lecturers and students to carry out an internet-based and digital learning process which has been minimally used in the world of education in the country [2]. Basically online learning relies on computer technology devices or gadgets and smartphones that connect lecturers and students interactively by utilizing online learning, including; Zoom Cloud, Edmodo, WhatsApp Group, Jitsi, Google Classroom, etc.

In fact, internet technology-based learning has many obstacles, such as software infrastructure (software applications) and hardware, such as gadgets or smartphones and computer facilities. Not to mention that there are still some lecturers or students who are "unfamiliar" with operating and using all of these devices or are "technologically illiterate". In addition, there are areas that are far from internet coverage or the signal is not strong enough or even non-existent. All of these conditions will complicate the learning process through this online media.

Therefore, this manuscript is important to explain how the design of the learning curriculum in the SI Study Program, PPs at UIN Raden Fatah Palembang can take place during the Covid-19 epidemic, and can run optimally and effectively. Especially considering that all this time the SI Study Program, PPs of UIN Raden Fatah has contributed greatly to the intellectual and social progress of society $[3,4]$, both in South Sumatra and on a national and regional scale.

As an integral part of UIN Raden Fatah, SI Study Program, carries out the vision; "To become a superior and leading Islamic Study Program in the development of Interdisciplinary Islamic scholarship based on universal Islamic values, nationally and internationally in 2025" [5]. It means that the SI Study Program is a new breakthrough to study the intellectual treasures of Islam as a religious tradition (historical Islam). Because Islam is not only a religion that contains a "set of doctrinal orders" (normative Islam), but also contains intellectual treasures as a religious tradition. This kind of thinking tendency has developed since decades ago in universities in the Western world [6].

Furthermore, Amin Abdullah [7] said that Islamic Studies as a scientific building with a theoretical framework approach must be based on the philosophy of Islamic sciences. The SI PPs Study Program at UIN Raden Fatah Palembang is a study program that examines Islamic scientific philosophy in various dimensions, both relating to the study of Islamic Economics 
and Finance (EKS), Islamic Law (HI), Educational Technology (TP), Administration and Public Policy (AKP), Teacher and Pedagogic Education (PGP), Arabic Language (BA), Curriculum Development (PK), Cultural and Media Studies (KBM), Gender and Children Studies (KGA), Politics and Government (PP), Sociology of Islam (SI), Population and Family Concentration (KK), and Malay Islamic Civilization (PIM).

\section{RESEARCH METHODS}

As a field research, the appropriate research data collection procedure is descriptive data [8]. Descriptive research tries to reveal facts by analyzing data [9-11]. There are two types of data sources, namely primary data sources and secondary data sources. According to Lofland \& Lofland as quoted by Lexy J. Moleong [12] the primary data source in qualitative research is words. The interviewee's words are the primary data source. Meanwhile, documentation data is a source of additional data or secondary data sources. The primary data source in this study is data obtained directly from informants in the field through interview techniques in accordance with the problems discussed in this study. The interview technique used is the snowball technique. Meanwhile, secondary data is obtained from research results, scientific journals, books, and others. The technique of checking the validity of the research data used triangulation techniques. According to Moleong [12], this technique is used to test the validity of data by comparing different sources. In this study, triangulation was used by examining the degree of validity of the data findings by comparing the methods used, comparing data sources and comparing between contexts when the data were obtained.

\section{A. Revolution Era 4.0 and SI Study Program, PPs at UIN Raden Fatah Palembang}

Since the status change from "IAIN to University", UIN Raden Fatah Palembang has made a serious commitment to becoming a superior university and can compete with quality universities in the country. According to Nata [13] there are several reasons behind the need to convert IAIN to UIN, including because the change from IAIN to UIN is a demand for professional, high-quality education and offers many choices so that it can face challenges and seize opportunities. Also, this conversion is an effort to converge general science and religion, as said Harun Nasution, the change from IAIN to a university was designed to eliminate the dichotomy of science [14]

If we are based on Azra's view, as quoted by Nata [15], the basic ideas and concepts of developing IAIN towards UIN cannot be separated from several problems faced by IAIN in its development so far. The problem is, there is an assumption that IAIN has not played an optimal role in the academic world, bureaucracy and Indonesian society because so far IAIN has played a more significant role in the context of da'wah. Besides, the IAIN curriculum has not been able to respond to developments in science and technology and the increasingly complex dynamics of society. In the context of converting
IAIN to UIN Raden Fatah, the SI Study Program is required to improve; 1. Quality of human resources, 2. Quality of service and 3. Infrastructure; so that UIN can be superior in the future, without obscuring the universality value of Islamic civilization as the core of the development of all characters from various scientific disciplines at large.

Abbas [16] states that the opening of new study programs, including the SI PPs Study Program at UIN Raden Fatah Palembang, is intended to answer the challenges of science, technology and art, as well as to meet the needs of society for graduates of a study program. Therefore, the opening of a study program must really consider its academic significance and its usefulness. Abbas's statement is indeed quite reasonable because opening an SI study program without careful consideration and tends to be in a hurry without considering academic and practical aspects, can have a fatal impact, because this new study program will produce graduates (alumni) who are not competent and have no quality. Especially for the master level, if the SI study program does not consider academic and practical aspects, in the end, the SI study program will only produce unqualified graduates as a result of the lack of competent education personnel because they do not have adequate facilities and limited reference materials which have an impact on research results that are not in accordance with the SI study program

As a first step, the SI PPs study program of UIN Raden Fatah Palembang has compiled a vision, mission, goals, and objectives as a derivative of the vision and mission of UIN Raden Fatah Palembang. The formulation of this vision and mission is very important considering that in terms of achieving a goal, the SI Postgraduate Study Program at UIN Raden Fatah Palembang, cannot be separated from planning and real action to make this happen. The vision of the SI Postgraduate Program at UIN Raden Fatah Palembang is "To become a superior and leading Islamic Study Program in the scientific development of Islamic studies based on universal Islamic values, nationally and internationally in 2025" [5]. The vision of this SI study program is an expectation of a realistic future and a desire to realize it within a certain period of time. In other words, a vision is a statement, whether spoken or written today, which is the current management process for reaching into the future.

In line with Akdon's [17] statement, vision is a formulation of the future which is the main reason for the establishment of a study program that includes main objectives and tasks. The vision is also a scheme of work programs related to other policy stakeholders that illustrates future challenges. This vision is described in the form of a mission [18]. Conclusion The mission of the UIN Raden Fatah SI PPs study program is to become a quality and universal Islamic-based study program, so that it can develop a research tradition to develop interdisciplinary science to benefit society [5].

There are 2 objectives for the establishment of the SI PPs Study Program at UIN Raden Fatah Palembang, namely general goals and specific goals. First, general purpose. The 
general objective refers to the objectives of the Postgraduate Program at the Raden Fatah State Islamic University of Palembang, which aims to guide, nurture and prepare masters who have competence and ability in intellectual academic aspects, moral attitudes, and holistic skills. In addition to being able to carry out research, academic development, integrity, high emotional and spiritual intelligence so that they are able to think inclusively, master the methodology of Islamic Studies carefully, act and assess every action taken in order to become intellectuals, and academics with universal Islamic insight. Second, specific goals. In this particular goal, PPs UIN Raden Fatah Palembang aims to prepare quality masters (S2), related to the quality of research in the interdisciplinary field of science that is beneficial to society [5].

In accordance with the vision, mission, and objectives of the SI PPs Study Program at UIN Raden Fatah Palembang, the profile of graduates is expected to have the ability in the field of education manager, as an educator (teacher or lecturer), an expert Islamic thinker, an expert in socio-religious research and experts in the field of curriculum design / academic Islamic education, as well as knowing Islamic civilization, have broad insight, think objectively, critically, innovatively, are inclusive and have a noble character. With these abilities, it is hoped that the profile of SI graduates can compete locally, nationally and internationally in the field of Islamic Education and Islamic Civilization with other universities. There are at least four (4) qualifications for SI graduates, namely; 1). Able to develop interdisciplinary Islamic studies in public or private institutions; 2). Able to conduct research in the field of religion which has national and international recognition; 3). Able to innovate and develop interdisciplinary Islamic studies in society; and 4). Able to analyze and solve community problems in the religious fields. Competency indicators for SI graduates include the following matters;

- Able to develop interdisciplinary Islamic studies in public or private institutions: a). Mastering the main sources of Islamic teachings in a comprehensive manner; b). Understand Islamic learning strategies in Higher Education; and c). Have the ability to master classical and contemporary Islamic literature.

- Able to conduct research in the field of religion and religion which has received national and international recognition: a). Become a scientific and religious developer philosopher; b). Understand social research methodology and religious research; c). Have the ability to design social and social religious research; and D). Producing scientific papers published in accredited journals, both nationally and internationally

- Able to innovate and develop Islamic studies in society: a). Able to develop contextual and systematic Islamic material; b). Skilled in conveying creative and innovative Islamic messages; and c). Able to engineer Islamic values in the context of multicultural community life.
- Able to analyze and solve community problems in the religious and religious fields; a). Have the ability to work with the community; b). Able to conduct social analysis; c). Able to do conflict resolution; and D). Able to motivate and develop a society based on Islamic values and national values

The supporting competencies in the SI study program are; 1). Able to be involved academically and practically; 2). Responsible, professional and ethical; and 3). Able to interact with the work environment and have high competitiveness. Meanwhile, other competencies include; 1). Able to conduct research related to various disciplines that can be implemented in society; 2). Able to manage work well; 3). Able to develop a career and assess their own performance; and 4). Able to increase professionalism.

In an effort to improve the quality of students and graduates, the SI PPs Study Program at UIN Raden Fatah Palembang has done many things in accordance with Presidential Regulation Number 8 of 2012 concerning the Indonesian National Qualification Framework, namely by implementing the KKNI curriculum since 2017. The SI study program is designed to be taken for 4 semesters ( 2 years). To achieve a Masters degree, students must complete a study load of 49 credits. The following is the distribution of the SI study program curriculum:

- Cross-Discipline Courses (Basic Competencies): 9 credits

- Concentration courses (Main Competencies): 18 credits

- Elective Courses (Supporting Competencies): 3 credits

- Research and Thesis Writing: 13 credits

Total: 43 credits

- Language:
a. Indonesian (TOIFL): 0 credit
b. English (TOEFL): 3 credits
c. Arabic (TOAFL): 3 credits

The emergence of the Industrial Revolution 4.0 (RI.4.0) era has been a main challenge for the SI study program, PPs, UIN Raden Fatah. In the RI.40 era, all universities in the world competed to innovate by strengthening their research base, because in this era competence and the ability to compete in the global era are the key words to be able to win the competition and stay afloat. In this condition, the SI study program, PPs, UIN Raden Fatah Palembang and its alumni must be able to compete so as not to be "crushed" by the vortex of global competition. One of the efforts to improve the quality of the SI study program, PPs, UIN Raden Fatah Palembang is through accreditation. Accreditation is legality for Higher Education or Study Programs regarding the quality of educational programs and the quality of their graduates. The standard used is the BAN-PT standard [19]. BAN-PT is an institution formed by the government as outlined in Government Regulation No. 
60/1999 which has the authority to carry out accreditation, at State Universities, Private Universities, Religious and Expertise Colleges, as well as other distance education programs [20,21].

For the SI study program, PPs, UIN Raden Fatah Palembang, the assessment of accreditation is very important, because it is used as a measure to improve the quality and quality assurance of the SI study program. The quality that you want to improve is related to academic and non-academic activities in accordance with the vision and mission. In the preparation of courses, the SI Study Program uses a team teaching mechanism, with the aim of encouraging students to have foreign language skills in Arabic and English. Not only that, the SI Study Program also strives to be consistent in publishing study program journals and encouraging students to do research. The SI study program also seeks to fund student assistance in the form of scholarships. In an effort to improve the quality of learning, the SI study program, PPs, UIN Raden Fatah Palembang has carried out a study of the learning process through feedback from lecturers, students, alumni, and graduate users regarding their expectations and perceptions. For more details, see table 1 , below:

TABLE I. LEARNING PROCESS FEEDBACK

\begin{tabular}{|c|c|c|}
\hline Feedback from & Feedback content & Follow up \\
\hline (1) & (2) & (3) \\
\hline \multirow[t]{4}{*}{ Lecturer } & $\begin{array}{l}\text { Suggest to held regular meetings between lecturers and postgraduate } \\
\text { leaders. }\end{array}$ & $\begin{array}{l}\text { Regular meetings are held between lecturers and } \\
\text { postgraduate leaders }\end{array}$ \\
\hline & Need an administration system, academic supporters, for KRS and KHS & $\begin{array}{l}\text { - Improved online system in filling in KRS and KHS as } \\
\text { well as accuracy (time \& validation) in entering scores. } \\
\text { - Reward and punishment will be made for the accuracy } \\
\text { of score submission }\end{array}$ \\
\hline & Need additional supporting facilities for the learning process. & $\begin{array}{l}\text { Currently, all classes have computers with a wifi internet } \\
\text { connection. }\end{array}$ \\
\hline & $\begin{array}{l}\text { Request for funding support for research activities and for module } \\
\text { development. }\end{array}$ & $\begin{array}{l}\text { The request is necessary to follow up and explore for } \\
\text { cooperation. }\end{array}$ \\
\hline \multirow[t]{8}{*}{$\begin{array}{l}\text { Postgraduate } \\
\text { Students }\end{array}$} & $\begin{array}{l}\text { Request for lecturer professionalism as seen from: } \\
\text { a. How lecturers start and end the lectures on time. } \\
\text { b. The presence of lecturers to carry out lectures. } \\
\text { c. If lecturers are unable to do a class, the lecturer should give news } \\
\text { beforehand. } \\
\text { d. If lecturers are unable to do a class, the lecturer should change the class } \\
\text { schedules. }\end{array}$ & $\begin{array}{l}\text { - Professional development of lecturer in education and } \\
\text { the learning process including soft skills through training } \\
\text { and workshops } \\
\text { - Granting permission to attend and or hold scientific } \\
\text { discussions, workshops and seminars both at the national } \\
\text { and international levels. }\end{array}$ \\
\hline & $\begin{array}{l}\text { The delivery of learning materials by lecturers is expected to: } \\
\text { a. Lecture materials are given following the lecture contract. } \\
\text { b. The lecturer seems to have mastered the lecture material given. } \\
\text { c. Lecturers are able to transfer knowledge to students well. } \\
\text { d. Lecturers can show examples of actual and factual cases that match the } \\
\text { lecture material. } \\
\text { e. Lecturers invite students to ask questions actively or discuss. } \\
\text { f. The lecturer delivers the material by being a discussion guide. }\end{array}$ & $\begin{array}{l}\text { - The lecturer has asked students to multiply the lecture } \\
\text { contract and syllabus before lectures are held. } \\
\text { - Because LCD facilities have been provided in the } \\
\text { lecture room, lecturers are expected to be able to use } \\
\text { creative and innovative learning by utilizing the } \\
\text { multimedia provided }\end{array}$ \\
\hline & $\begin{array}{l}\text { Lecturer Ethics and How to Interact with Students: } \\
\text { a. Lecturers are polite in a class and social life. } \\
\text { b. Lecturers uphold discipline and ethics in the learning process. } \\
\text { c. The lecturer gives time out of the class to explain the lecture material. }\end{array}$ & \\
\hline & $\begin{array}{l}\text { Evaluation / Monitoring of Learning Process: } \\
\text { a. Lecturers should conduct tests or evaluations of learning as a schedule } \\
\text { planned. } \\
\text { b. Lecturers give assignments, quizzes, tests or evaluations in accordance } \\
\text { with the lecture material. } \\
\text { c. Lecturers give feedback, corrections, assessments of tests or } \\
\text { evaluations carried out, and announce them openly. }\end{array}$ & $\begin{array}{l}\text { - The scoring system has been carried out as transparent } \\
\text { as possible. } \\
\text { - There is already a Guidebook for the Assessment } \\
\text { System } \\
\text { - The KHS system has been facilitated online. } \\
\text { - There is a remedy facility }\end{array}$ \\
\hline & $\begin{array}{l}\text { Lecturer performance in lecturing activities, proposal and writing thesis } \\
\text { guidance, also academic guidance. }\end{array}$ & $\begin{array}{l}\text { Lecturer staff development in education and the learning } \\
\text { process including soft skills. }\end{array}$ \\
\hline & $\begin{array}{l}\text { Ease of use of facilities, infrastructure and implementation of } \\
\text { extracurricular activities. }\end{array}$ & $\begin{array}{l}\text { SOPs are made to regulate the use of facilities and the } \\
\text { implementation of activities. }\end{array}$ \\
\hline & Difficulty in tuition fee payment & $\begin{array}{l}\text { - Provision of scholarships from various parties } \\
\text { (especially scholarships from the Provincial Education } \\
\text { Office, Bidik Misi, City and Provincial Baznas, and } \\
\text { Academic Achievement awards. } \\
\text { - Tuition fee payment dispensation facility }\end{array}$ \\
\hline & Graduate user & $\begin{array}{l}\text { Soft skills and hard skills have been taught in an } \\
\text { integrated and connected manner. }\end{array}$ \\
\hline
\end{tabular}


The SI Study Program, PPs of UIN Raden Fatah Palembang has implemented a policy of academic freedom by giving freedom to students to determine research topics that suit their interests. Lecturers are given the freedom to provide lecture materials that are suitable for scientific developments, likewise, with the methods used in the lecture process. Besides, the Study Program also provides facilities and infrastructure for carrying out academic activities that are related to academic competencies and do not violate applicable laws and regulations. The freedom of the educational platform in the form of hearing events in the Student Communication Forum, the Scientific Work community, exchanging knowledge in the activities of the English Club and Arabic Club students, etc.

In addition, at the beginning of each semester, the SI Study Program provides an opportunity for students to have a dialogue with the Director of postgraduate studies to voice their aspirations and opinions. In each lecture, students are given the freedom to convey their knowledge and opinions in lectures, through the presentation of papers by students individually or in groups. In every seminar on a national or international scale, SI Study Program students are always involved as committee and participants. Students are also always involved in lecturer research activities. Together with students, lecturers and other academicians engaged in network development in the form of partnerships with universities at home and abroad, the activities include (1) holding national and international seminars, training and workshops between universities, both domestic and foreign; (2) conduct educational visits to other universities, both domestic and overseas.

\section{B. Islamic Studies Study Program Learning Curriculum Design in the Covid-19 Pandemic Era}

The Covid-19 pandemic has affected the learning process in the SI Study Program PPs at UIN Raden Fatah for the last seven months. In accordance with the Circular (SE) of the Ministry of Education and Culture No. 4/2020 so that the learning process in schools and colleges that is face to face must be temporarily stopped. Students are expected to be able to do "lectures" at home through the distance learning method (online). Basically, for SI Study Program students, online lectures are not a problem. Because based on Van Kerkhove's research, with internet-based technology, people can connect with other people without being in the same place or room (class) [22]. This means that the learning process between lecturers and students can still be carried out without being blocked by the room by utilizing information technology [23]. Based on the We Are Social Research report, the "Digital Reports 2020" released at the end of January 2020 states that nearly 64 percent of Indonesia's population is connected to the internet. The number of internet users in Indonesia has reached 175.4 million out of the total population of Indonesia which amounts to around 272.1 million. Compared to 2019, the number of internet users in Indonesia has increased by around 17 percent or 25 million users in 2020 [24].

Lecturers and students of the SI PPs study program at UIN Raden Fatah, have long been using learning systems based on internet network technology (online), for example through WhatsApp (WA), Google Class, the Zoom application, YouTube, or other media that can support learning media. Lecturers and students interact with each other in the learning process, through discussions or by assigning assignments to students with measurable tasks in accordance with the objectives of the course material. This means that lectures can still be done by breaking through the walls of the room (conventional lectures). However, the online learning process demands the role of lecturers to evaluate effectiveness according to student needs $[25,26]$, because sometimes online learning, indirectly affects student absorption [27].

The lecturer of the SI study program at UIN Raden Fatah should be innovative and creative in compiling a learning curriculum design. The curriculum must be designed as concise and straightforward as possible to deliver effective and efficient course materials (lecture methods), especially in this online learning system. For example, lecturers can make a summary in the form of a PowerPoint, or a vlog containing lecture tutorials, and so on. Lecturers also have to compile achievements and learning activities as well as assessment methods that are following the Semester Learning Plan (RPS). The duration of learning must also be adjusted to the credit unit load taken by students. Determining the length of each learning unit is very important, especially in assigning assignments to students. Do not let the tasks given to students take too much time so that the student learning load becomes much higher than the credit load they carry.

All of this is inseparable from the ability of the lecturer to master online learning applications. Because until now, there are not a few lecturers who are still slow in responding to student learning activities. Furthermore, as indicated by the Rector of UIN Raden Fatah Palembang, Prof. H.M. Sirozi, not a few lecturers are only able to use the WhatsApp (WA) application in the online lecture process, and lecturers give more assignments to students and lecturers still review very little of lecture material [28].

During the Covid-19 pandemic, the SI study program, PPS, UIN Raden Fatah, Palembang has intensively carried out an online learning process, such as through the WhatsApp (WA) media, the Zoom application, and the like [29]. The same thing was said by AK Bukhori, that the learning process in the SI Study Program has been carried out, both related to the teaching and learning activity process, and the monitoring system [30]. Furthermore, the SI Study Program has also conducted thesis guidance, proposal examinations, eligibility exams, and open exams, through an online system [31].

Zesulkan said that; in the era of the Industrial Revolution 4.0 (RI.4.0), the use of digital technology based on internet technology is very important to be implemented so that we are able to interact with other people [32]. When everyone is familiar with the learning system using an online system, when the Covid-19 pandemic passes, distance learning is no longer foreign and has even become a culture in the learning system in education. 


\section{CONCLUSION}

Based on the description above, it can be concluded that during the Covid-19 pandemic, the learning process was carried out using an online system (long-distance) for students of the SI study program, PPS, UIN Raden Fatah, Palembang. Lecturers are required to be innovative and creative in compiling a concise and straightforward learning curriculum design, with the aim that the course material (lecture method) can be implemented effectively and efficiently. The existing Semester Learning Plan (RPS) does not have to be changed, but it needs to be adjusted to the learning process in accordance with current conditions, namely by means of e-learning.

So far, lecturers of the SI study program, PPS, UIN Raden Fatah, Palembang are not "technologically illiterate" in implementing online learning. This made the SI study program, PPS, UIN Raden Fatah, Palembang able to compete in the Industrial Revolution Era 4.0 (ERI.4.0), an era marked by the use of digital technology based on internet technology.

\section{REFERENCES}

[1] Menteri Pendidikan, Surat Edaran Nomor 3 Tahun 2020 Tentang Pelaksanaan Pendidikan dalam Masa Darurat CoronaVirus (COVID-19), (2020)

[2] Setiawan, 2020

[3] Prayoto, "Peran Perguruan Tinggi Dalam Pengembangan IPTEK". Panel Acience, Seminar Nasional Dies Natalis ke-45 UGM, 20-21 Desember 1994

[4] T. Sugiharto, "Peran Perguruan Tinggi Dalam Meningkatkan Pertumbuhan Ekonomi melalui Pasar Modal: Is Entrepreneuria University the Answer?". Makalah disajikan pada Seminar Nasional Pasar Modal "Dunia Akademis Sebagai Jembatan Masyarakat Berinvestasi di Pasar Modal", Auditorium Universitas Gunadarma Jakarta, 17 Desember 2008.

[5] Buku III A Borang Akreditasi Prodi Studi Islam S2 Pascasarjana UIN Palembang Tahun 2018, (Palembang: Pascasrajana UIN Raden Fatah, 2018)

[6] K. Zada, "Orientasi Studi Islam di Indonesia". Dalam http://www. uinjkt.ac.id/id/orientasi-studi-islam-di-indonesia/. Diakses 2 April 2018 , pukul 19.00 WIB

[7] M.A. Abdullah, Islamic Studies di Perguruan Tinggi, Pendekatan Integratif-Interkonektif, (Yogyakarta: Putaka Pelajar, 2006)

[8] S. Margono, Metodologi Penelitian Pendidikan, (Jakarta: Rineka Cipta, 1997)

[9] N. Muhajir, Metode Penelitian Kualitatif, (Yogyakarta: Rake Sarasin, 1996)

[10] S. Arikunto, Prosedur Penelitian; Suatu Pendekatan Praktik, Edisi Revisi, (Jakarta: PT. Rineka Cipta, 1992), hlm. 10.

[11] Sukardi, Metodologi Penelitian Kompetensi dan Praktiknya, (Jakarta: PT. Bumi Aksara, 2005)

[12] L.J. Moleong, Metodologi Penelitian Kualitatif, (Bandung: Rosda Karya, 1996)

[13] A. Nata, Manajemen Pendidikan, Cet. 5, (Jakarta: Kencana Prenada Media Group, 2010)
[14] Kusmana and Y. Munadi (ed.), Proses Perubahan IAIN Menjadi UIN Syarif Hidayatullah Jakarta, (Ciputat: Jakarta UIN Press, 2002)

[15] A. Nata, (et.al.), Dari Ciputat, Cairo, Hingga Colombia, (Jakarta: IAIN Jakarta Press, 2002)

[16] S. Abbas, Manajemen Perguruan Tinggi: Beberapa Catatan, (Jakarta: Prenadamedia, 2014)

[17] Akdon, Strategis Managemen for Educational Management, (Bandung: Alfabeta. 2006).

[18] A. Calam and A. Qurniati, "Merumuskan Visi dan Misi Lembaga Pendidikan". Dalam Jurnal Saintikom, Vol.15, No. 1, Januari, (Medan: Lembaga Penelitian dan Pengabdian Kepada Masyarakat (LPPM) STMIK Triguna Dharma, (2016)

[19] A. Mandagi, "Peningkatan Peringkat Akreditasi Program Studi: Tantangan Terhadap Penjaminan Mutu dan Kualitas Pelayanan di Era Globalisasi”. Dalam Jurnal Teknik dan Ilmu Komputer, Vol. 02, No. 07 Juli-September, (2013), hlm. 307-308

[20] S. Sugiyono and A. Nuryanto, Laporan Penelitian Studi Evaluasi Performance Program Studi PGSD Pasca Akreditasi, (Jakata: Badan Akreditasi Nasional Perguruan Tinggi Tahun 2012)

[21] BAN-PT: Standar dan Prosedur Akreditasi Institusi Perguruan Tinggi, Buku II, Standar dan Prosedur, (Jakarta: Badan Akreditasi Nasional Perguruan Tinggi, 2011)

[22] D. Putri, "Pendidik Digital di Masa Pandemi”. Dalam https://bakaba.co/pendidik-digital-di-masa-pandemi/; dan KumparanTECH, "Riset: 64\% Penduduk Indonesia Sudah Paka Internet”. Dalam https://kumparan.com/kumparantech/riset-64 penduduk-indonesia-sudah-pakai-internet-1ssUCDbKILp/full. Diakses 21 Februari 2020, pukul 8.01 WIB.

[23] Husniyatu Salamah Zainiyati, 2017

[24] R. Pakpahan and Y. Fitriani, “Analisis Pemanfaatan Teknologi Informasi Dalam Pembelajaran Jarak Jauh di Tengah Pendemi Corona Covid-19”. Dalam JISAMAR (Journal of Information System, Applied, Management, Accounting and Researh), Vol. 4 No.2 Mei 2020

[25] D. Dai and G. Lin, “Online Home Study Plan for Postponed 2020 Spring Semester during the COVID-19 Epidemic: A Case Study of Tangquan Middle School in Nanjing, Jiangsu Province, China". Dalam SSRN Electronic Journal. https://doi.org/ 10.2139/ssrn.3555539; 2020;

[26] L.V. Herliandry, M.E.S. Nurhasanah, and H. Kuswanto, Pembelajaran Pada Masa Pandemi Covid-19. "Jurnal Teknologi Pendidikan”, Vol. 22, No. 1, April (2020)

27] W.A.F. Dewi, Dampak Covid-19 terhadap Implementasi Pembelajaran Daring di Sekolah Dasar. "Jurnal Edukatif: Jurnal Ilmu Pendidikan", Vol 2 No 1 April (2020)

[28] Z. Blandino, "Banyak Dosen UIN Gaptek, Kasih Materi Kuliah, Cuma Lewat WhatsApp" Dalam https://sibernas.com/banyak-dosen-uingaptek-kasih-materi-kuliah-cuma-lewat-whatsapp/. Diakses 19 Jun 2020, pukul 8.11 WIB

[29] Wawancara dengan Kaprodi SI, Ahmad Zainuri, pada 2 Juni 2020, puku 09.00 WIB di Ruang Kerja Kaprodi SI, Pascasarjana UIN Raden Fatah Palembang

[30] Wawancara dengan, AK. Bukhori, pada 2 Juni 2020, pukul 10.00 WIB di Ruang Dosen Kaprodi SI, Pascasarjana UIN Raden Fatah Palembang

[31] Wawancara dengan, Meesya Maulina Ismana, Sutarmizi, dan Merry Yanto, pada 2 Juni 2020, pukul 11.10 WIB di Pascasarjana UIN Raden Fatah Palembang

[32] M. Yahya, "Era Industri 4.0: Tantangan dan Peluang Perkembangan Pendidikan Kejuruan Indonesia". Orasi Ilmiah Professor bidang Ilmu Pendidikan Kejuruan Universitas Negeri Makassar Tanggal 14 Mare 2018 